\title{
Erratum
}

\section{Site-specific characteristics of infants developing bronchopulmonary dysplasia}

MA Khan, B Kuzma-0'Reilly, NL Brodsky and V Bhandari

Journal of Perinatology (2006) 26, 524. doi:10.1038/sj.jp.7211567

Correction to: Journal of Perinatology (2006) 26, 428-435. doi:10.1038/sj.jp.7211538

Following the publication of the above paper, the author identified the following errors in the text:

Page 428:

Abstract, Study Design. Line 1 should read 'Records of 306 infants of $\leqslant 30$ weeks...'
Materials and methods. Line 1 should read 'Medical records of 306 infants (gestational age $(\mathrm{GA}) \leqslant 30$ weeks) ...'

Page 431.

Line 2 should read '...and 29 to 30 weeks (group 3).'

Page 432.

Discussion. Line 19 should read ' ... of BPD (in infants $\leqslant 30$ weeks GA).' 